Key Words:

DWPF, hydrogen

Noble metals

Acid usage

Retention:

Permanent

\title{
SLUDGE CHARACTERIZATION AND SRAT SIMULATIONS USING A NITRITE-FREE SLUDGE SIMULANT
}

\author{
D. C. Koopman
}

DECEMBER 2009

Savannah River National Laboratory

Savannah River Nuclear Solutions

Aiken, SC 29808 


\section{DISCLAIMER}

This work was prepared under an agreement with and funded by the U.S. Government. Neither the U. S. Government or its employees, nor any of its contractors, subcontractors or their employees, makes any express or implied:

1. warranty or assumes any legal liability for the accuracy, completeness, or for the use or results of such use of any information, product, or process disclosed; or

2. representation that such use or results of such use would not infringe privately owned rights; or

3. endorsement or recommendation of any specifically identified commercial product, process, or service.

Any views and opinions of authors expressed in this work do not necessarily state or reflect those of the United States Government, or its contractors, or subcontractors.

Printed in the United States of America

Prepared for

U.S. Department of Energy 
Key Words:

DWPF, Noble

Metals, $\mathbf{H}_{2}$,

Acid Usage

Retention:

Permanent

\section{SLUDGE CHARACTERIZATION AND SRAT SIMULATIONS USING A NITRITE-FREE SLUDGE SIMULANT}

D. C. Koopman

DECEMBER 2009

Savannah River National Laboratory

Savannah River Nuclear Solutions

Savannah River Site

Aiken, SC 29808

Prepared for the U.S. Department of Energy Under

Contract Number DE-AC09-08SR22470 


\section{REVIEWS AND APPROVALS}

D. C. Koopman, Process Technology Programs

Date

M. E. Stone, Peer Reviewer, Process Technology Programs

Date

C. C. Herman, Manager, Process Technology Programs

Date

S. L. Marra, Manager,

Date

Environmental \& Chemical Process Technology Research Programs

J. E. Occhipinti, Manager

Date

Waste Solidification Engineering

- ii - 


\section{TABLE OF CONTENTS}

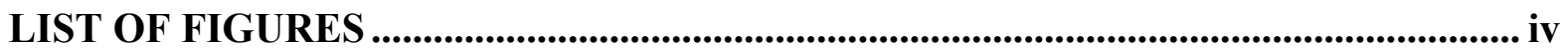

LIST OF TABLES ........................................................................................................................ iv

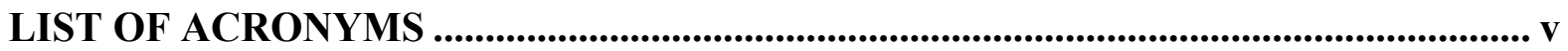

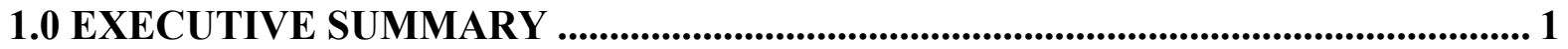

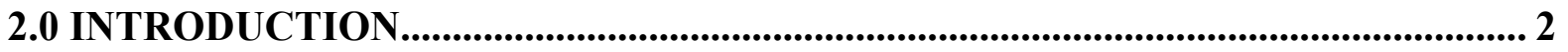

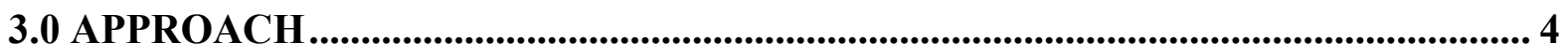

3.1 Process and Sample Analytical Methods........................................................................... 4

3.2 Simulant Preparation and Characterization ...................................................................... 4

3.3 Chemical Process Cell Simulation Details..................................................................... 7

4.0 SRAT SIMULATION RESULTS .................................................................................... 9

4.1 Anion Composition Changes ................................................................................................ 9

4.2 Elemental and Dissolution Data ................................................................................... 9

4.3 Probe Data.......................................................................................................................... 11

4.4 Off-gas Data ..................................................................................................................... 13

4.5 Data Implications for Catalytic Hydrogen Generation................................................. 16

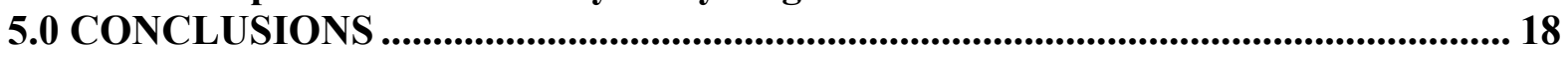

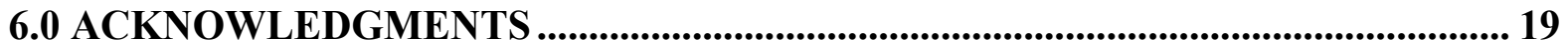

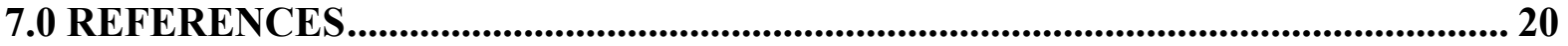




\section{LIST OF FIGURES}

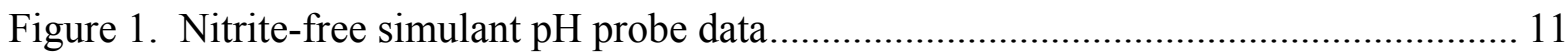

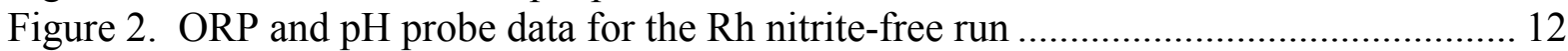

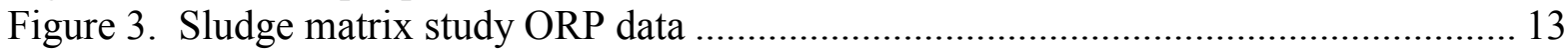

Figure 4. Carbon dioxide production at DWPF scale ........................................................ 14

Figure 5. Carbon dioxide production after acid at DWPF scale ........................................... 14

Figure 6. Off-gas moisture to $\mathrm{GC}$ as function of dryer time on-line ...................................... 16

\section{LIST OF TABLES}

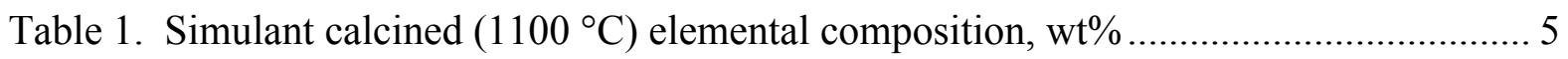

Table 2. Other nitrite-free simulant analyses ....................................................................... 6

Table 3. Noble metal and mercury targets, $\mathrm{wt} \%$ in total solids ............................................... 6

Table 4. Noble metal and mercury targets, $\mathrm{mg} / \mathrm{kg}$ slurry ...................................................... 7

Table 5. Stoichiometric acid calculation results, moles acid/L slurry ................................... 7

Table 6. Anion concentration, $\mathrm{mg} / \mathrm{kg}$, end of SRAT cycle .................................................... 9

Table 7. Anion reaction extents in SRAT cycle, \% .......................................................... 9

Table 8. Extents of dissolution at the end of SRAT cycle, \% ............................................. 10

Table 9. SRAT product calcined $\left(1100{ }^{\circ} \mathrm{C}\right)$ elemental composition, $\mathrm{wt} \%$............................ 10 


\section{LIST OF ACRONYMS}

$\begin{array}{ll}\text { ACTL } & \text { Aiken County Technology Laboratory } \\ \text { AD } & \text { Analytical Development } \\ \text { CPC } & \text { Chemical Process Cell } \\ \text { CSTR } & \text { Continuous Stirred Tank Reactor } \\ \text { DWPF } & \text { Defense Waste Processing Facility } \\ \text { E\&CPT } & \text { Environmental and Chemical Process Technology } \\ \text { FAVC } & \text { Formic Acid Vent Condenser } \\ \text { GC } & \text { Gas Chromatograph } \\ \text { IC } & \text { Ion Chromatography } \\ \text { ICP-AES } & \text { Inductively Coupled Plasma-Atomic Emission Spectroscopy } \\ \text { ICP-MS } & \text { Inductively Coupled Plasma-Mass Spectroscopy } \\ \text { LWO } & \text { Liquid Waste Organization } \\ \text { MWWT } & \text { Mercury Water Wash Tank } \\ \text { NFT } & \text { Nitrite free test } \\ \text { PSAL } & \text { Process Science Analytical Laboratory } \\ \text { QA } & \text { Quality Assurance } \\ \text { SB } & \text { Sludge Batch } \\ \text { SCFM } & \text { Standard Cubic Feet per Minute } \\ \text { SME } & \text { Slurry Mix Evaporator } \\ \text { SRAT } & \text { Sludge Receipt and Adjustment Tank } \\ \text { SRNL } & \text { Savannah River National Laboratory } \\ \text { SRNS } & \text { Savannah River Nuclear Solutions } \\ \text { SRR } & \text { Savannah River Remediation } \\ \text { STI } & \text { Scientific and Technical Information } \\ \text { TA } & \text { Technical Analyst } \\ \text { TIC } & \text { Total Inorganic Carbon } \\ \text { TR } & \text { Technical Report }\end{array}$




\subsection{EXECUTIVE SUMMARY}

Understanding catalytic hydrogen generation is fundamental to the safe operation of the Defense Waste Processing Facility (DWPF) Chemical Process Cell (CPC). Two Sludge Receipt and Adjustment Tank (SRAT) simulations were completed at the Aiken County Technology Laboratory (ACTL) of the Savannah River National Laboratory (SRNL) using a nitrite-free starting simulant. One simulation was trimmed with $\mathrm{Rh}$ and $\mathrm{Hg}$ and the other with $\mathrm{Ru}$ and $\mathrm{Hg}$. The two noble metals were trimmed at the upper end of the recent Rh-Ru$\mathrm{Hg}$ study. Mercury was trimmed at $1.5 \mathrm{wt} \%$ in the total solids. Excess acid comparable in quantity to that in the recent $\mathrm{Rh}-\mathrm{Ru}-\mathrm{Hg}$ matrix study was used. In spite of the favorable conditions for hydrogen generation, virtually no hydrogen production was observed during either SRAT simulation.

The $\mathrm{Rh}$ test result confirmed the postulated significance of nitrite ion to the catalytic reactions producing hydrogen in CPC testing with normal DWPF sludge simulants. As for $\mathrm{Ru}$, however, previous testing has shown that $\mathrm{Ru}$ activated for hydrogen generation only after nitrite destruction. Therefore, $\mathrm{Ru}$ could have potentially been catalytically active from the start of the nitrite-free SRAT test, but no such activity was seen. The nitrite-free Ru test result suggests that the intermediate form detected in the bead-frit melter feed preparation $\mathrm{Ru}$ solubility profiles was some form of nitro- $\mathrm{Ru}$ complex. The nitro-Ru complex is apparently not catalytically active for hydrogen generation but is a precursor to the catalytically active form (presumably a different complex not involving nitrite ligands). Removing nitrite ion from the system prevented the Ru catalyst precursor from forming and consequently blocked formation of the catalytically active form.

These results, along with the results of a simulation in which sodium nitrite was metered into the SRAT to prevent ligand substitution reactions that occur during nitrite destruction from occurring in order to reduce hydrogen generation, have greatly clarified the role of the nitrite ion in SRAT hydrogen generation. The new findings add to the overall fundamental understanding of catalytic hydrogen generation during waste processing in the DWPF. These findings also address one of the issues raised in the Future Work section of the recent summary document concerning catalytic hydrogen generation in the CPC. ${ }^{1}$ The knowledge gained should facilitate planning future experiments. 


\subsection{INTRODUCTION}

SRNL has been researching the chemistry of catalytic hydrogen generation in the DWPF $\mathrm{CPC}$. This program has identified $\mathrm{Rh}, \mathrm{Ru}$, nitrite ion, $\mathrm{Hg}$, and excess acid as the five principal factors. These conclusions were presented in a recent status summary report, which includes references that lead to most relevant prior work on the subject. ${ }^{1}$ The maximum hydrogen generation rate in the SRAT often occurred near the end of nitrite destruction and was correlated with the $\mathrm{Rh}$ concentration. Some simulations, however, had a greater maximum hydrogen generation rate occur after nitrite destruction which was due to a catalytic contribution from $\mathrm{Ru}$ that exceeded the maximum hydrogen generation rate due to $\mathrm{Rh}$.

Nitrite was found to have an impact on both $\mathrm{Rh}$ and $\mathrm{Ru}$ catalysis. $\mathrm{Rh}$ was active in converting nitrite to $\mathrm{N}_{2} \mathrm{O}$ when nitrite concentrations were greatly in excess of the $\mathrm{Rh}$ concentration. Destruction of all of the remaining available nitrite seemed to be associated with deactivation of the principal $\mathrm{Rh}$ catalyst. Conversely, Ru appeared to be nearly inactive at high nitrite ion concentrations. Ru would activate for hydrogen generation only after nitrite ion concentrations were reduced to comparable or lower levels than the $\mathrm{Ru}$ concentration. Mercury, which generally inhibited catalytic hydrogen generation to some extent in direct comparison SRAT simulations with and without mercury, was found to catalyze the reductive conversion of nitrite to $\mathrm{NO}$ and $\mathrm{CO}_{2}$ by formic acid. Altering the rate of nitrite destruction will change the timing of catalytic hydrogen generation by both $\mathrm{Rh}$ and $\mathrm{Ru}$.

The analysis of the experimental data led to a few questions that were included as areas for future work in the status summary report: ${ }^{1}$

First, $\mathrm{Ru}$ seemed to go through a transitional form based on solubility data before the catalytically active form for hydrogen generation appeared. The identity of both forms remains unknown. Literature data suggests that Ru-carbonyl complexes may be one candidate for the hydrogen catalyst. Absorbed $\mathrm{CO}_{2}$ from decomposition of formic acid may be the key to forming such complexes, since the initial carbonate in the sludge is typically consumed several hours before Ru becomes active.

Second, how much of the inferred $\mathrm{Rh}$ and $\mathrm{Ru}$ hydrogen catalysis control by nitrite ion is actually due to the changing background concentration of nitrite? Would hydrogen generation occur in the absence of nitrite altogether? Sodium nitrite solution was metered into an earlier SRAT simulation once GC data indicated that the catalyst(s) had become active for hydrogen. This strategy was successful in partially suppressing hydrogen generation, and it showed the potential to be even more effective with an improved $\mathrm{NaNO}_{2}$ addition strategy.

Third, why does mercury inhibit catalysis in head-to-head tests performed with and without mercury present and everything else equal? The more detailed analysis so far has only found $\mathrm{Hg}$ to be important at altering the timing of nitrite destruction. In addition, even small 
amounts of $\mathrm{Hg}$ in the starting sludge ( $\sim 0.1 \mathrm{wt} \%$ in total solids) cause significant changes in hydrogen generation compared to identical sludges without mercury. Changing the timing of hydrogen generation through altered nitrite destruction kinetics has the potential to either increase or decrease the maximum hydrogen generation rate (increase by aligning the most active catalyst form with a greater quantity of excess acid). Investigations targeted to determine what is different between a simulant without mercury and one with a low concentration of mercury are not planned, since there are no mercury-free waste sludges to feed DWPF in the SRS tank farm (the question is apparently hypothetical except for special simulant sludge tests and in the preparation of mercury-free melter feed simulants).

Progress on the first two questions above was thought to be possible if a simulant could be prepared that was nitrite-free. The Sludge Batch 6 parametric simulant properties study had produced some unwashed, untrimmed simulant during transitions in the precipitation vessel conditions. This excess simulant was nitrite-free. A portion of this simulant was taken, washed, and trimmed to supernate concentrations similar to recent SRAT tests in the hydrogen generation program (except for the absence of nitrite). This nitrite-free simulant was used to perform two SRAT simulations. One SRAT was trimmed with rhodium nitrate solution and $\mathrm{HgO}$. The other was trimmed with soluble $\mathrm{RuCl}_{3}$ and $\mathrm{HgO}$. It was hypothesized that the $\mathrm{Rh}$ test might produce very minimal hydrogen, since the nitro-Rh complexes would not form in the absence of nitrite (unless some nitrate ions were to convert to nitrite ions). It was further hypothesized that the $\mathrm{Ru}$ test might produce significant hydrogen, and that this hydrogen might be seen earlier than normal (for $\mathrm{Ru}$ ), due to the absence of the inhibiting nitrite ion. This report summarizes the preparation of the nitritefree simulant and the results obtained performing these two nitrite-free SRAT simulations. 


\subsection{APPROACH}

\subsection{PROCESS AND SAMPLE ANALYTICAL METHODS}

The automated data acquisition system developed for the 4-L SRAT rigs was used to collect electronic data. Collected data included SRAT temperature, bath temperatures for the cooling water to the SRAT condenser and Formic Acid Vent Condenser (FAVC), slurry pH, SRAT mixer speed and torque, air and helium purge flows (He is used as an internal standard and is set to $0.5 \%$ of the nominal SRAT air purge flow). Cumulative acid addition volume data were collected from the automated dispensers. Both tests had a pH probe in the SRAT slurry to monitor $\mathrm{pH}$. Raw GC data were acquired on separate computers dedicated to each instrument.

Agilent 3000A micro GC's were used on both runs. The GC's were baked out before runs. Column-A can collect data related to $\mathrm{He}, \mathrm{H}_{2}, \mathrm{O}_{2}, \mathrm{~N}_{2}, \mathrm{NO}$, and $\mathrm{CO}$, while column-B can collect data related to $\mathrm{CO}_{2}$ and $\mathrm{N}_{2} \mathrm{O}$ (and sometimes water). GC's were calibrated with a standard gas containing $0.499 \mathrm{vol} \% \mathrm{He}, 1.000 \mathrm{vol} \% \mathrm{H}_{2}, 20.00 \mathrm{vol} \% \mathrm{O}_{2}, 51.0 \mathrm{vol} \% \mathrm{~N}_{2}, 25.0$ vol $\% \mathrm{CO}_{2}$ and 2.50 vol $\% \mathrm{~N}_{2} \mathrm{O}$. Room air was used to give a two point calibration for $\mathrm{N}_{2}$. The GC's were checked with calibration gas before and after the SRAT cycle.

The chilled off-gas leaving the FAVC was passed through a Nafion dryer in counter-current flow with a dried air stream to reduce the moisture content at the GC inlet. A fairly short unit was selected to minimize pressure drop, but it appears to be possible to significantly reduce the moisture content in the stream being sampled by the GC. The inlet GC samples also passed through small sintered metal filters prior to injection into the two columns. The dryer and filter are part of a program to extend GC service life.

Process samples were analyzed by various methods. Slurry and supernate elemental compositions were determined for the simulant and two SRAT products by inductively coupled plasma-atomic emission spectroscopy (ICP-AES) at the Process Science Analytical Laboratory (PSAL). Slurry samples were calcined at $1100^{\circ} \mathrm{C}$, however, so noble metals, $\mathrm{Pb}$, and $\mathrm{Cr}$ were underreported. Total slurry noble metal concentrations were determined using mass balance information. Soluble slurry anions were determined by ion chromatography (IC) on 100-fold weighted dilutions of slurry with water after filtering out insoluble solids. Starting simulant was submitted to Analytical Development (AD) for total inorganic carbon (TIC) analysis of both the total slurry and the supernate. Starting sludge and SRAT products were analyzed for slurry and supernate density using the Anton-Parr instrument at ACTL. Starting sludge was titrated to $\mathrm{pH} 7$ using the ACTL auto-titrator to determine the base equivalents for input into the stoichiometric acid equation.

\subsection{SIMULANT PREPARATION AND CHARACTERIZATION}

A somewhat unique simulant was prepared for this study. The CSTR precipitator parametric study produced a fairly wide range of compositions due to the range of precipitation $\mathrm{pH}$ values that were studied. Some of these were very low in aluminum and very high in 
manganese. The recipe basis was that for the Sludge Batch 6 (SB6) nominal washed case in the preliminary flowsheet study (SB6-A simulant). ${ }^{2}$ The actual composition, was, however, quite different from that of the preliminary SB6 simulant.

Table 1 presents the average elemental analytical results from duplicate analyses of sample of the simulant. The sample was calcined at $1100^{\circ} \mathrm{C}$ followed by digestion for slurry elemental analysis.

Table 1. Simulant calcined $\left(1100{ }^{\circ} \mathrm{C}\right)$ elemental composition, $\mathbf{w t} \%$

\begin{tabular}{|c|c|}
\hline Element & Nitrite-free Simulant \\
\hline $\mathrm{Al}$ & 6.54 \\
\hline $\mathrm{Ba}$ & 0.208 \\
\hline $\mathrm{Ca}$ & 3.31 \\
\hline $\mathrm{Ce}$ & 0.306 \\
\hline $\mathrm{Cr}$ & 0.291 \\
\hline $\mathrm{Cu}$ & 0.132 \\
\hline $\mathrm{Fe}$ & 24.1 \\
\hline $\mathrm{K}$ & $<0.10$ \\
\hline $\mathrm{La}$ & 0.147 \\
\hline $\mathrm{Mg}$ & 2.01 \\
\hline $\mathrm{Mn}$ & 9.65 \\
\hline $\mathrm{Na}$ & 11.7 \\
\hline $\mathrm{Ni}$ & 5.26 \\
\hline $\mathrm{P}$ & $<0.10$ \\
\hline $\mathrm{Pb}$ & 0.047 \\
\hline $\mathrm{S}$ & 0.376 \\
\hline $\mathrm{Si}$ & 0.564 \\
\hline $\mathrm{Sn}$ & 0.021 \\
\hline $\mathrm{Ti}$ & 0.038 \\
\hline $\mathrm{Zn}$ & 0.148 \\
\hline $\mathrm{Zr}$ & 0.218 \\
\hline
\end{tabular}

Table 2 gives $w t \%$ solids, density, titration, anion and inorganic carbon data for the nitritefree simulant along with comparable results for the hydrogen program simulant used in most of the 2006-2008 catalytic hydrogen program testing. The key input parameters for stoichiometric acid equation calculations are included in Table 2. 
Table 2. Other nitrite-free simulant analyses

\begin{tabular}{|l|c|c|}
\hline & $\begin{array}{c}\text { Nitrite-free } \\
\text { Simulant }\end{array}$ & $\begin{array}{c}\text { H2 }_{\text {Program }} \\
\text { Simulant }\end{array}$ \\
\hline Total solids, $\mathrm{wt} \%$ & 15.2 & 22.8 \\
\hline Insoluble solids, wt\% & 10.8 & 16.8 \\
\hline Soluble solids, $\mathrm{wt} \%$ & 4.4 & 6.0 \\
\hline Calcined solids, wt\% & 11.4 & 16.0 \\
\hline Slurry density, g/mL & 1.10 & 1.18 \\
\hline Supernate density, g/mL & 1.04 & 1.05 \\
\hline Slurry base equiv., $\mathrm{mol} / \mathrm{kg}$ & 0.539 & 0.313 \\
\hline \hline Nitrite, $\mathrm{mg} / \mathrm{kg}$ & $<100$ & 17,900 \\
\hline Nitrate, $\mathrm{mg} / \mathrm{kg}$ & 15,200 & 13,800 \\
\hline Sulfate, $\mathrm{mg} / \mathrm{kg}$ & 1,100 & 1,600 \\
\hline Oxalate, $\mathrm{mg} / \mathrm{kg}$ & $<100$ & 1,400 \\
\hline Chloride, $\mathrm{mg} / \mathrm{kg}$ & 188 & 390 \\
\hline Slurry TIC, $\mathrm{mg} / \mathrm{kg}$ & 732 & 660 \\
\hline Supernate $\mathrm{TIC}, \mathrm{mg} / \mathrm{kg}$ & 360 & 1430 \\
\hline
\end{tabular}

The nitrite-free simulant was considerably more viscous than the hydrogen program simulant. Consequently, it was impractical to increase the $\mathrm{wt} \%$ total solids of the nitrite-free simulant to match those of the hydrogen program simulant. Both nitrite-free simulant SRAT tests had 3,000 $\mathrm{g}$ of starting sludge (before trim chemicals and rinse water). Rh was trimmed as a $4.93 \mathrm{wt} \%$ rhodium solution of $\mathrm{Rh}\left(\mathrm{NO}_{3}\right)_{3}$. Ru was added as the dry trivalent chloride salt at a purity of $41.73 \mathrm{wt} \% \mathrm{Ru}$. Mercury was trimmed as dry $\mathrm{HgO}$.

The noble metal targets for the two nitrite-free simulant tests were matched to the high end concentrations in the $\mathrm{Rh}-\mathrm{Ru}-\mathrm{Hg}$ matrix study. ${ }^{3}$ These concentrations are $5 / 3^{\text {rd }}$ the mid-point concentrations in that study. This choice offset the fact that the total solids concentration was only about $2 / 3^{\text {rd }}$ as high $(\sim 2 / 3 * 5 / 3 \approx 1)$. Therefore, the noble metal concentrations in the nitrite-free SRAT simulations were comparable to the midpoint concentrations in the $\mathrm{Rh}-\mathrm{Ru}-$ $\mathrm{Hg}$ matrix study on a slurry basis (mg noble metal/kg slurry). The two nitrite-free tests, NFT1 and NFT2, mercury and noble metal targets are given in Table 3 as $\mathrm{wt}^{\mathrm{t}} \%$ in the total solids of the trimmed slurry along with two comparison cases from the Rh- $\mathrm{Ru}-\mathrm{Hg}$ matrix study, the midpoint case and the high Rh-high Ru-low Hg case, H-H-L. Silver and palladium were excluded from the two nitrite-free SRAT simulations to eliminate any potential confounding effects on the results.

Table 3. Noble metal and mercury targets, $w \mathrm{t} \%$ in total solids

\begin{tabular}{|l|l|l|l|l|l|}
\hline & \multicolumn{1}{|c|}{$\mathbf{A g}$} & \multicolumn{1}{|c|}{ Pd } & Rh & Ru & Hg \\
\hline Rh-Ru-Hg midpoint & 0.0010 & 0.0003 & 0.0078 & 0.0300 & 1.500 \\
\hline Rh-Ru-Hg H-H-L & 0.0010 & 0.0003 & 0.0130 & 0.0500 & 0.500 \\
\hline NFT1 & 0 & 0 & 0.0131 & 0 & 1.500 \\
\hline NFT2 & 0 & 0 & 0 & 0.0505 & 1.500 \\
\hline
\end{tabular}


The slurry concentrations of the noble metals and mercury are given in Table 4.

Table 4. Noble metal and mercury targets, mg/kg slurry

\begin{tabular}{|l|c|c|c|r|c|}
\hline & Ag & Pd & Rh & Ru & Hg \\
\hline RhRuHg midpoint & 2.3 & 0.7 & 18 & 68 & 3420 \\
\hline RhRuHg H-H-L & 2.3 & 0.7 & 30 & 114 & 1140 \\
\hline NFT1 & 0 & 0 & 20 & 0 & 2280 \\
\hline NFT2 & 0 & 0 & 0 & 77 & 2280 \\
\hline
\end{tabular}

\subsection{CHEMICAL PROCESS CELL SIMULATION DETAILS}

The trimmed SRAT receipt volume was about $2.6 \mathrm{~L}$. The amount of acid to add was not determined by selecting an arbitrary stoichiometric factor. The stoichiometric acid requirement of the hydrogen program simulant and the nitrite-free simulant were determined using the new Koopman minimum acid requirement equation: ${ }^{4}$

$$
\frac{\text { moles acid }}{\text { L slurry }}=\text { base equivalents }+H g+\text { soluble } T I C+1.5 *(C a+M g)+1.0 * \text { nitrite }+1.5 * M n
$$

The amount of acid used in the Rh-Ru-Hg matrix study SRAT simulations above the Koopman minimum acid calculation value was determined by difference to be about 0.61 moles acid/L SRAT receipt slurry. That incremental quantity of additional acid was added to the stoichiometric requirement determined for the nitrite-free simulant to obtain the total acid addition for the SRAT simulations. The results of these calculations are summarized in Table 5.

Table 5. Stoichiometric acid calculation results, moles acid/L slurry

\begin{tabular}{|l|c|c|c|}
\hline & $\begin{array}{c}\text { Min. Koopman } \\
\text { moles/L }\end{array}$ & $\begin{array}{c}\text { Actual } \\
\text { moles/L }\end{array}$ & $\begin{array}{c}\text { Stoichiometric } \\
\text { factor }\end{array}$ \\
\hline $\mathrm{Rh}-\mathrm{Ru}-\mathrm{Hg}$ & 1.41 & 2.02 & $143 \%$ \\
\hline Nitrite-free & 1.22 & 1.83 & $150 \%$ \\
\hline
\end{tabular}

The higher base equivalents of the nitrite-free simulant partially off-set the absence of nitrite, as did the higher Mn concentration. The net result was that the stoichiometric factor only changed from $143 \%$ to $150 \%$. The essential goal was to ensure that there was a reasonable quantity of excess acid available in the two nitrite-free tests for producing hydrogen should either noble metal become catalytically active at levels comparable to normal SRAT simulations. Constraining this goal was the desire to not create a potential situation where hydrogen generation would greatly exceed the equivalent to the DWPF design basis limit of $0.65 \mathrm{lbs}_{2} / \mathrm{hr}$ in the off-gas system.

Total acid was partitioned between formic and nitric acids using the latest RedOx equation. ${ }^{5}$ An assumption of $20 \%$ formate loss was also made to enable this calculation to be performed 
without any prior experience with these simulants. As a result, formic acid made up $94.5 \%$ of the total acid.

Nominal scaled DWPF SRAT processing conditions were generally used. The SRAT cycle, however, did not have a heel from a prior batch.

- The SRAT air purge scaled to $230 \mathrm{scfm}$ in DWPF.

- A 200 ppm antifoam addition was made prior to nitric acid addition.

- A 100 ppm antifoam addition was made prior to formic acid addition.

- Nitric and formic acid addition were made at $93^{\circ} \mathrm{C}$.

- Acid was added at two gallons per minute scaled from 6,000 gallons to $2.6 \mathrm{~L}$.

- A $500 \mathrm{ppm}$ antifoam addition was made prior to going to boiling following acid addition.

- Boiling assumed a condensate production rate of 5,000 lbs/hr at DWPF scale.

- SRAT dewatering was performed to adjust the slurry volume and meet the SRAT total solids target (about 80-90 minutes).

- Reflux followed dewatering. The end of a 12-hour reflux period defined the end of the SRAT cycle. It was projected that mercury might exceed the DWPF SRAT product limit after only 13-14 total hours at boiling due to the high initial concentration. This was not relevant to this particular study which was focused on catalytic hydrogen generation.

The SRAT product slurry was sampled directly into a digestion bottle while mixing once it had cooled to $90{ }^{\circ} \mathrm{C}$. These samples were for possible mercury analysis. The remaining SRAT product samples were taken after the product had cooled and been weighed. The MWWT and FAVC were drained and weighed. A complete SRAT simulation took about 21 hours measured from the start of heating prior to acid addition in the SRAT until the time that the SRAT product had cooled to less than $50^{\circ} \mathrm{C}$. 


\subsection{SRAT SIMULATION RESULTS}

This section discusses the processing and analytical data obtained from the two nitrite-free SRAT simulations.

\subsection{ANION COMPOSITION CHANGES}

SRAT product samples were taken and analyzed for elements, anions, solids, etc. These samples were taken once the SRAT had cooled to below $50{ }^{\circ} \mathrm{C}$. Results are presented for the anions and the slurry $\mathrm{pH}$ in Table 6 . The end of reflux $\mathrm{pH}$ is from the $\mathrm{pH}$ probe in the SRAT vessel at about $101{ }^{\circ} \mathrm{C}$, while the SRAT product sample $\mathrm{pH}$ is from a separate analytical probe used by PSAL on room temperature samples.

Table 6. Anion concentration, mg/kg, end of SRAT cycle

\begin{tabular}{|l|c|c|}
\hline & NFT1-Rh & NFT2-Ru \\
\hline Nitrite ion - product & $<100$ & $<100$ \\
\hline Formate ion - product & 66,700 & 66,600 \\
\hline Nitrate ion - product & 23,300 & 23,500 \\
\hline Sulfate ion - product & 150 & $<100$ \\
\hline SRAT pH, end of reflux & 4.22 & 4.18 \\
\hline SRAT product sample pH & 4.71 & 4.79 \\
\hline
\end{tabular}

Nearly identical results were obtained for the two SRAT products. The similarity was consistent with the identical acid additions and general lack of catalytic activity observed.

Anion data were combined with material balance data. The resulting calculations were used to determine the formate loss. The pre-run acid calculations were prepared assuming $20 \%$ formate loss. The results of these calculations are given in Table 7 along with the calculated RedOx state as indicated by the $\mathrm{Fe}^{2+} / \Sigma \mathrm{Fe}$ for a SME product assumed to be at $45 \mathrm{wt} \%$ total solids given the SRAT product analyses.

Table 7. Anion reaction extents in SRAT cycle, \%

\begin{tabular}{|l|c|c|}
\hline & NFT1-Rh & NFT2-Ru \\
\hline Formate loss & 15 & 16 \\
\hline $\mathrm{Fe}^{2+} /$ Fe total (post-run) & 0.24 & 0.23 \\
\hline
\end{tabular}

\subsection{ELEMENTAL AND DISSOLUTION DATA}

The two SRAT product samples were analyzed for bulk and supernate elements. The results of calculations on extent of elemental dissolution are given in Table 8. 
Table 8. Extents of dissolution at the end of SRAT cycle, \%

\begin{tabular}{|l|c|c|c|c|c|c|c|}
\hline & $\mathrm{Ca}$ & $\mathrm{Mg}$ & $\mathrm{Mn}$ & $\mathrm{Ni}$ & $\mathrm{Rh}$ & $\mathrm{Ru}$ & $\mathrm{S}$ \\
\hline NFT1-Rh & 84 & 86 & 68 & 38 & 27 & - & 53 \\
\hline NFT2-Ru & 83 & 76 & 66 & 30 & - & 1.8 & 42 \\
\hline
\end{tabular}

Calcium dissolution extent remained near $80 \%$ as seen in several sets of recent SRAT products from different starting simulants. Magnesium extent of dissolution was about $81 \%$ which was lower than the $\sim 100 \%$ expected. The moderately high $\mathrm{Ni}$ dissolution extent (compared to many tests where the extent is near zero) also seems to indicate conditions were favorable for $100 \% \mathrm{Mg}$ dissolution. Manganese extent of dissolution was about $2 / 3^{\text {rd }}$ of the total indicating either partial reduction or total reduction with partial re-precipitation. The extent of sulfur dissolution indicates potential formation of sulfate precipitates.

The bulk elemental composition of the calcined solids from the two SRAT product slurries calcined solids is given in Table 9.

Table 9. SRAT product calcined $\left(1100{ }^{\circ} \mathrm{C}\right)$ elemental composition, wt\%

\begin{tabular}{|c|c|c|}
\hline Element & NFT1-Rh & NFT2-Ru \\
\hline $\mathrm{Al}$ & 6.75 & 6.66 \\
\hline $\mathrm{Ba}$ & 0.227 & 0.220 \\
\hline $\mathrm{Ca}$ & 3.15 & 3.03 \\
\hline $\mathrm{Ce}$ & 0.224 & 0.222 \\
\hline $\mathrm{Cr}$ & 0.268 & 0.267 \\
\hline $\mathrm{Cu}$ & 0.096 & 0.124 \\
\hline $\mathrm{Fe}$ & 23.4 & 23.7 \\
\hline $\mathrm{K}$ & $<0.10$ & $<0.10$ \\
\hline $\mathrm{La}$ & 0.136 & 0.127 \\
\hline $\mathrm{Mg}$ & 2.10 & 2.13 \\
\hline $\mathrm{Mn}$ & 9.45 & 9.53 \\
\hline $\mathrm{Na}$ & 13.1 & 13.0 \\
\hline $\mathrm{Ni}$ & 5.23 & 5.22 \\
\hline $\mathrm{P}$ & $<0.10$ & $<0.10$ \\
\hline $\mathrm{Pb}$ & 0.020 & 0.027 \\
\hline $\mathrm{S}$ & 0.382 & 0.381 \\
\hline $\mathrm{Si}$ & 0.680 & 0.711 \\
\hline $\mathrm{Sn}$ & 0.098 & 0.097 \\
\hline $\mathrm{Ti}$ & 0.021 & 0.021 \\
\hline $\mathrm{Zn}$ & 0.212 & 0.210 \\
\hline $\mathrm{Zr}$ & 0.206 & 0.217 \\
\hline
\end{tabular}

Results for the two SRAT products were very similar as expected given the common starting sludge simulant. 


\subsection{PROBE DATA}

Data on the $\mathrm{pH}$ of the SRAT slurry during processing were obtained in both runs. Data on the oxidation-reduction potential (ORP) of the SRAT supernate were obtained during the rhodium simulation. Data on $\mathrm{pH}$ profiles for the two runs are given in Figure 1.

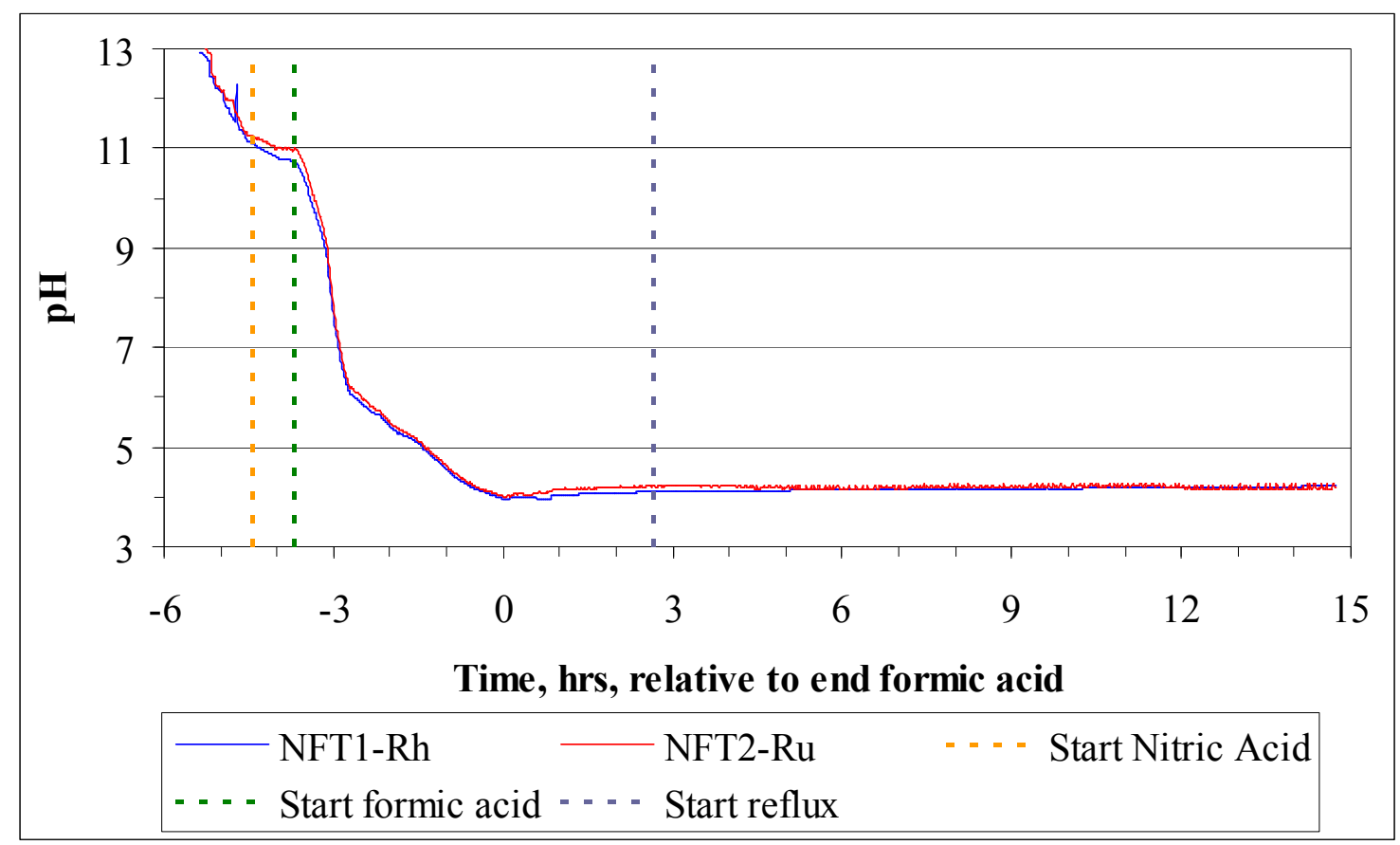

Figure 1. Nitrite-free simulant pH probe data

The two $\mathrm{pH}$ profiles were essentially identical suggesting that $\mathrm{Rh}$ and $\mathrm{Ru}$ were either both inactive (most likely) or that they did exactly the same thing in both simulations (unlikely). The lack of significant rise after acid addition indicates low catalytic activity and low formate destruction.

Both $\mathrm{pH}$ and ORP probe data were obtained on the rhodium run. The data are given in Figure 2. The ORP probe reading is in relative millivolts. 
SRNL-STI-2009-00673, REVISION 0

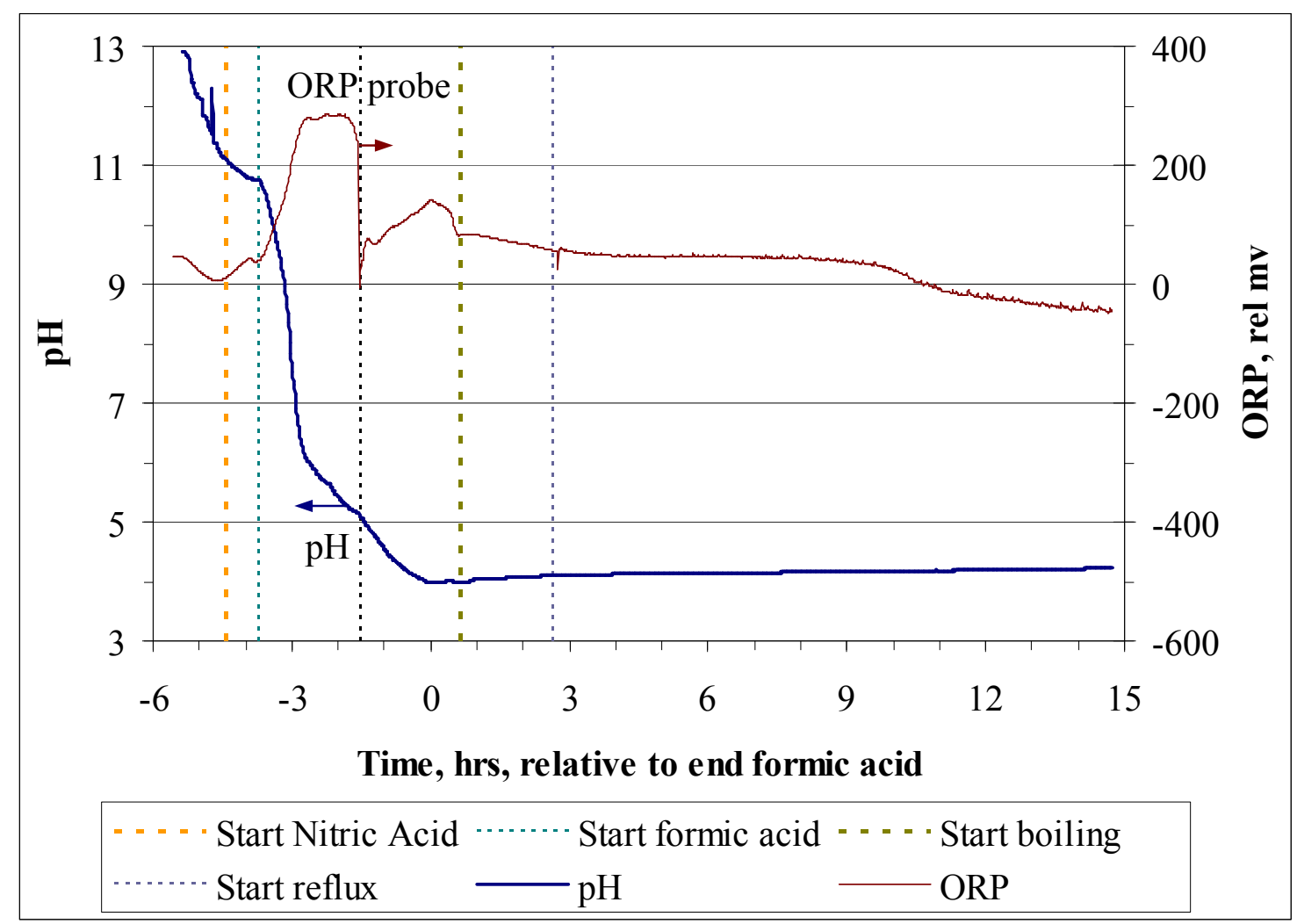

Figure 2. ORP and pH probe data for the $\mathrm{Rh}$ nitrite-free run

The ORP probe was checked against two "standard solutions". The nominal ORP potentials of the standard solutions are uncertain by $\pm 10 \%$. The ORP probe was reading high by $30-60$ $\mathrm{mV}$ during the testing. One large ORP feature was seen during formic acid addition centered at about 2.5 hours before the end of formic acid addition. This was in contrast to a pair of comparably large features that were seen in two of the recent sludge matrix study runs, Figure 3. 
SRNL-STI-2009-00673, REVISION 0

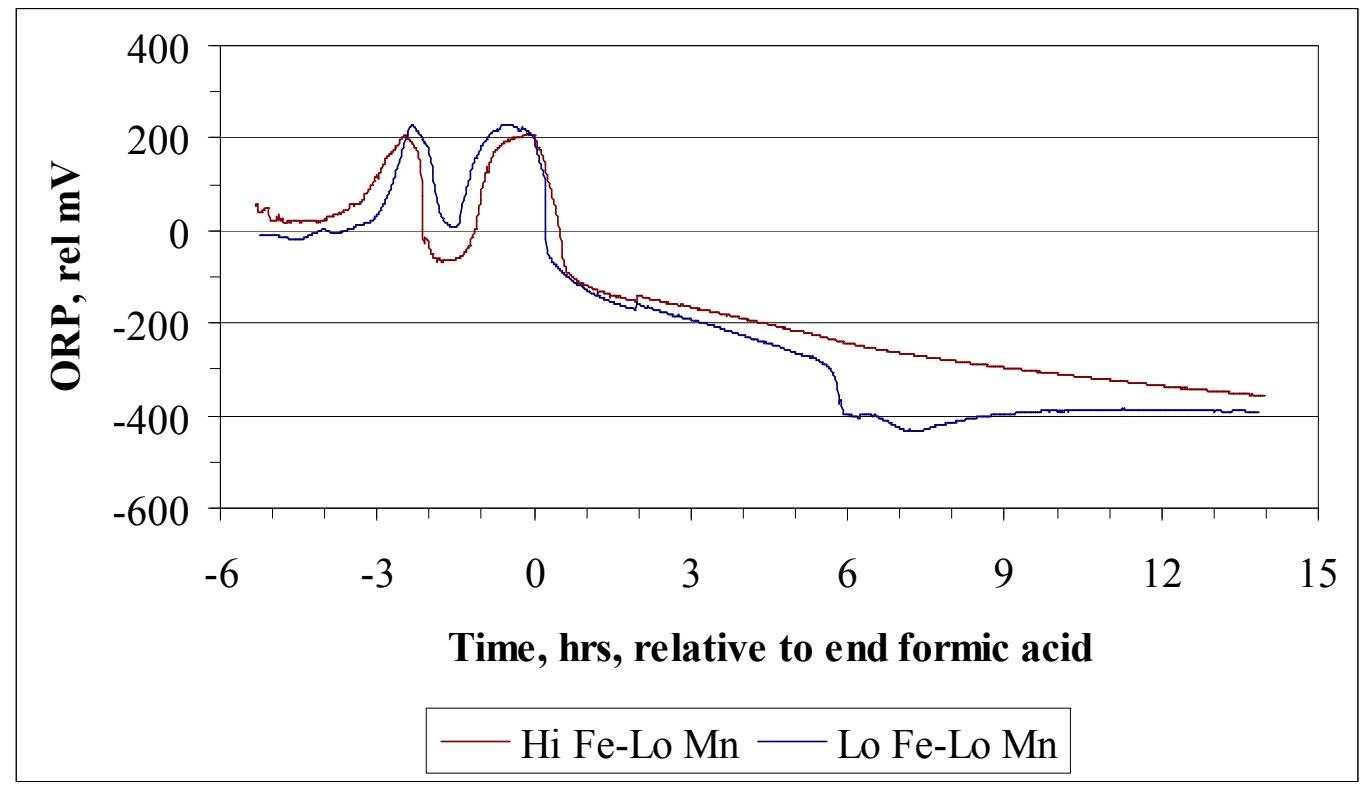

Figure 3. Sludge matrix study ORP data

The primary feature in the nitrite-free $\mathrm{Rh}$ run seemed to occur over roughly similar $\mathrm{pH}$ ranges to the first peak in the sludge matrix study runs. In particular, the initial feature in both runs came as the $\mathrm{pH}$ was dropping rapidly from nine into the acidic range.

There was a suggestion of a second feature in the nitrite-free run with a small peak at about a half hour before the end of formic acid addition, but it was much less pronounced than in the sludge matrix study. Nevertheless, the timing was comparable. This period is normally dominated by nitrite destruction reactions and manganese reduction. The sludge matrix study had these reactions occurring in parallel, while the nitrite-free run had only manganese reduction. That may offer a clue as to the interpretation of these features. ORP data will continue to be collected and the results correlated as future SRAT simulations are performed.

\subsection{OFF-GAS DATA}

GC data were obtained during both runs. The major finding from the GC data was the near total absence of any hydrogen generation in both tests. The run with $\mathrm{Rh}$ sporadically produced hydrogen just above the detection limit of the GC, while the run with Ru did not produce detectable hydrogen. The $\mathrm{Rh}$ data do not generate a smooth curve (the hydrogen peak went above and below the detection limit multiple times), so no graph is given. It is noteworthy that there was so little noble metal catalytic activity indicated in either run in the total absence of nitrite ion.

Peaks for $\mathrm{NO}$ and $\mathrm{N}_{2} \mathrm{O}$ were not observed on the chromatographs of either run. No visual observations of any golden color in the off-gas were made. This was generally expected before the runs, but there was still the possibility that some nitrate ion might convert into nitrite and be destroyed producing these gases. 
Data for $\mathrm{CO}_{2}$ were fairly similar for the two runs, though not identical, Figure 4.

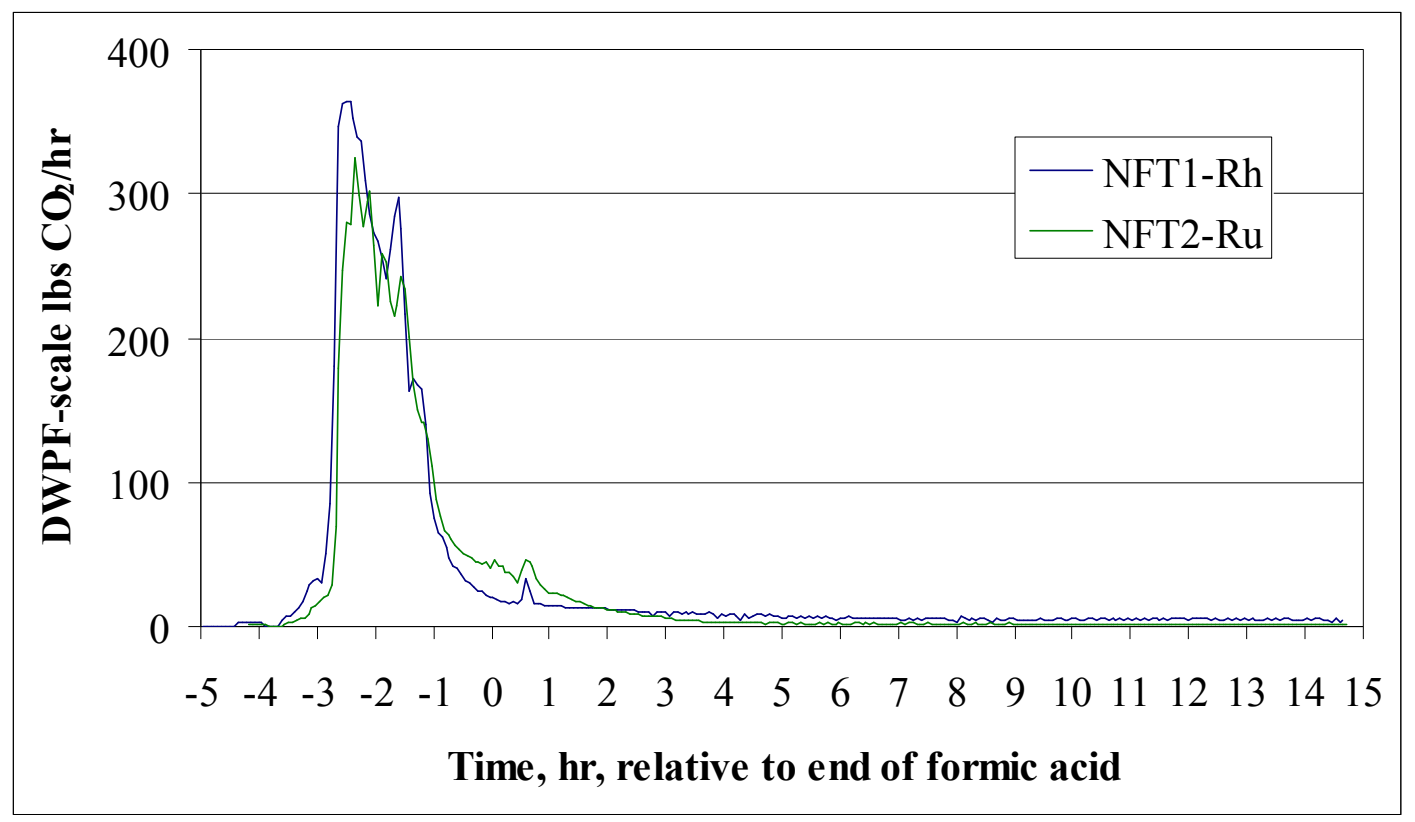

Figure 4. Carbon dioxide production at DWPF scale

The $\mathrm{Rh}$ run produced more $\mathrm{CO}_{2}$ initially. The Ru run produced more $\mathrm{CO}_{2}$ from -1 hour to +2 hours. The $\mathrm{Rh}$ run produced about 2.5 times as much $\mathrm{CO}_{2}$ as the $\mathrm{Ru}$ run from +2 hours until the end of reflux. Reflux started at +2.7 hours, or after the time when the $\mathrm{Rh}$ went from lower to higher than the $\mathrm{Ru}$ run in $\mathrm{CO}_{2}$ production rate. The post-acid addition GC data are expanded in Figure 5.

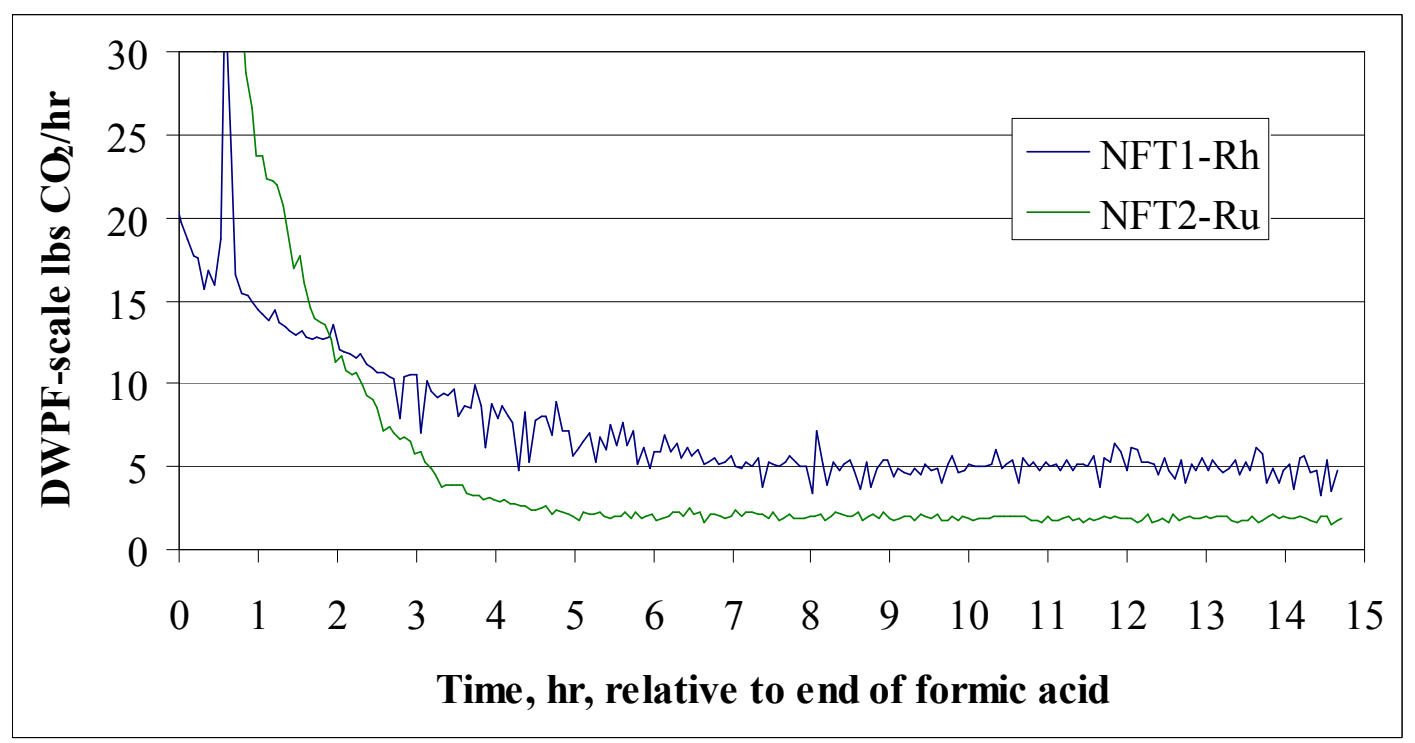

Figure 5. Carbon dioxide production after acid at DWPF scale 
The greater $\mathrm{CO}_{2}$ production rate during reflux in the $\mathrm{Rh}$ run compared to the $\mathrm{Ru}$ run may indicate some mild level of catalytic activity in the $\mathrm{Rh}$ run that was absent in the $\mathrm{Ru}$ run. This would be consistent with the trace quantities of hydrogen seen in the Rh run.

The $\mathrm{Rh}$ run produced $34.4 \mathrm{~g}$ of $\mathrm{CO}_{2}$ versus $29.7 \mathrm{~g}$ in the $\mathrm{Ru}$ run. The $\mathrm{Ru}$ run number is the more uncertain of the two. The uncertainty was due to issues with the accuracy of the internal standard gas, He, area calibration factor. The helium peak was superimposed on a sloped baseline caused by an internal back flush feature in this particular GC that could not be disabled.

Destruction of carbonate, reduction of $\mathrm{Hg}$, and reduction of about $67 \%$ of the $\mathrm{Mn}$ (per Table 8) should produce 11.0, 1.6, and $17.8 \mathrm{~g}$ of $\mathrm{CO}_{2}$ respectively, or $30.4 \mathrm{~g}$ total which is consistent with the $\mathrm{GC}$ data. It also seems to imply that $\mathrm{Mn}$ reduction did not reach $100 \%$ at any intermediate point in the SRAT cycle, however, which is not the expected outcome of a SRAT run with significant excess acid and a sustained low $\mathrm{pH}$.

The IC data for formate indicated a 31-32 g loss of formate (difference of formic acid in and the SRAT product formate out). If destroyed formate makes $\mathrm{CO}_{2}$, then combining this with the carbonate destruction should have made $41.8 \mathrm{~g}$ of $\mathrm{CO}_{2}$. This is $22 \%$ more than the $\mathrm{Rh}$ run result of $34.4 \mathrm{~g}$ and appears to be outside the likely range of random error for the integrated $\mathrm{CO}_{2}$ total ( $\mathrm{GC}$ calibrations held well during the runs and the $\mathrm{He} \mathrm{MKS}$ flow controller is unlikely to be off by $20 \%$, especially when it gives the proper vol $\% \mathrm{He}$ when combined with purge air prior to starting the SRAT cycle). SRAT product formate mass was about $180 \mathrm{~g}$, and this number could be uncertain by 10-20 g which would cover the difference with the GC data. Nevertheless, the two separate run results were nearly identical, and $30 \mathrm{~g}$ of formate loss is just enough to reduce all of the $\mathrm{Hg}$ and $\mathrm{Mn}$ that were present in the simulant.

One hypothesis that could reconcile the GC and IC data is that a fraction of the formate loss was either reabsorbed as insoluble carbonate or bicarbonate precipitate or was released as another gas. It was also noted that the ratio of $\mathrm{O}_{2} / \mathrm{N}_{2}$ increased during the main $\mathrm{CO}_{2}$ peak (this region is normally obscured by $\mathrm{O}_{2}$ consumption due to reaction with $\mathrm{NO}$ during tests with nitrite containing feeds). The ratio then returned to the normal range after the main $\mathrm{CO}_{2}$ peak. Molecular oxygen is not a presumed byproduct of $\mathrm{MnO}_{2}$ reduction. The presumed reaction is given by:

$$
\mathrm{MnO}_{2}+3 \mathrm{HCOOH} \rightarrow \mathrm{Mn}(\mathrm{HCOO})_{2}+\mathrm{CO}_{2}+\mathrm{H}_{2} \mathrm{O}
$$

The observation about the $\mathrm{O}_{2} / \mathrm{N}_{2}$ ratio may or may not be related, but it could imply that some variation of the above chemistry was occurring. For example, conversion of Mn(IV) to $\mathrm{Mn}(\mathrm{III})$ instead of $\mathrm{Mn}(\mathrm{II})$ would be expected to produce half as much $\mathrm{CO}_{2}$.

The GCs have been found to be able to detect the presence of water vapor in the off-gas. By adjusting the column injection interval, the water peak is generally kept out of the region of the $\mathrm{B}$ column where $\mathrm{CO}_{2}$ and $\mathrm{N}_{2} \mathrm{O}$ elute. The water peak is actually moving through the column very slowly, and the peak is usually from one injection earlier than the one producing 
the $\mathrm{CO}_{2}$ and $\mathrm{N}_{2} \mathrm{O}$ peaks. The water peak area was used to monitor the impact of the Nafion dryer on the moisture content of the off-gas leaving the chilled condenser. Compressed air was fed through a Drier-Rite column and then fed counter-currently to the off-gas in the Nafion dryer. A ratio of five to one was used for the dried air flow to the SRAT purge air flow. The uncalibrated moisture content of the off-gas as a function of time is given in Figure 6 (units are microvolt-seconds, that is raw GC integration units).

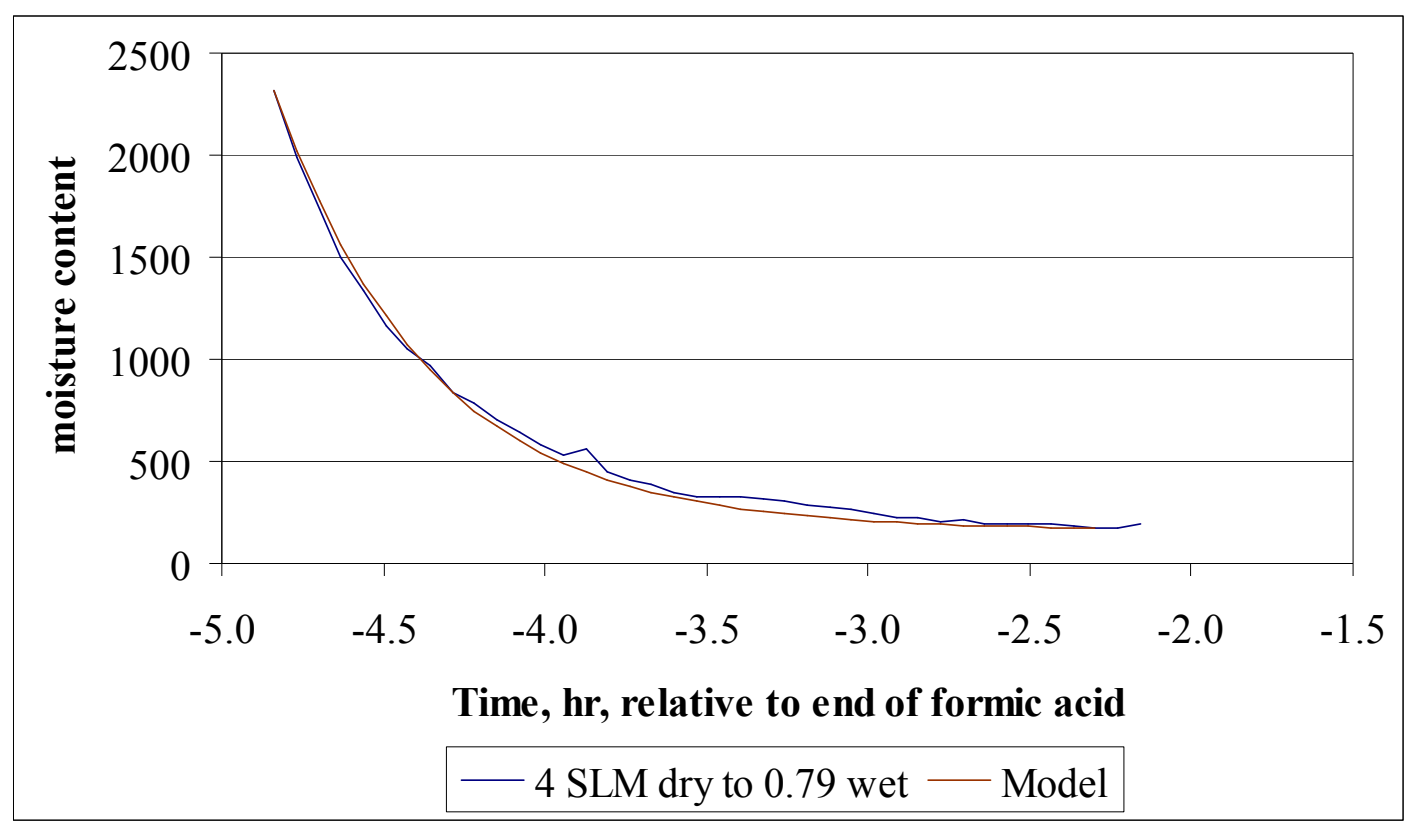

Figure 6. Off-gas moisture to GC as function of dryer time on-line

The model function contained an exponential decay function with a pre-exponential factor, exponent multiplier constant for time, and an additive constant.

$$
\text { moisture content }=2166 e^{-2.1 * \text { deltat }}+163
$$

where delta $t$ was the elapsed time from the start of drying. A $92 \%$ reduction in the moisture content of the chilled air coming out of the $4{ }^{\circ} \mathrm{C}$ condenser was achieved after about two hours. The additive constant, 163, may or may not approximate the moisture content of the dry air purge, but in any case, it is not expected that the dryer could reduce the moisture content of the chilled off-gas air below the moisture content of the dry air purge. It is thought that reducing the moisture content of the gas injected into the GCs will prolong their service life due to reduced corrosion attack from nitric and nitrous acids. Data were not obtained for NFT2, since the water peak fell outside the recorded period of the chromatographs ( 3 minutes of data are recorded out of a 4.5 minute sampling cycle).

\subsection{DATA IMPLICATIONS FOR CATALYTIC HYDROGEN GENERATION}

As discussed in the catalytic hydrogen generation status report, a growing body of evidence had been accumulated that tended to support the concept of a nitro-Rh complex as the 
primary active form of rhodium for hydrogen production. ${ }^{1}$ Rhodium-based production of hydrogen was detected at low nitrite ion concentrations near the end of nitrite destruction. The primary peak due to rhodium seemed to end as nitrite destruction went to completion. Residual catalytic activity of rhodium existed, but the form of the active species was unknown. The new data from the nitrite-free Rh test fully support these preliminary conclusions and hypotheses about the mechanism of catalytic rhodium driven hydrogen generation. It may even be necessary for rhodium to pass through the nitro-Rh complex stages before it can transition into a less active form. The current test did not appear to ever form a nitrite ligand-free less active form.

Less was known about catalytic hydrogen generation by $\mathrm{Ru}$ prior to the nitrite-free $\mathrm{Ru}$ test. The new data do not alter the conclusions in the summary status report. ${ }^{1}$ The total lack of hydrogen production, however, was not anticipated. The earlier data indicated that $\mathrm{Ru}$ became catalytically active once nitrite was essentially destroyed. In the absence of nitrite ion, it was assumed that Ru might become catalytically active immediately, or at least once a certain $\mathrm{pH}$ range was reached where Ru solubility combined with the presence of excess acid would lead to hydrogen generation. It had been postulated that a nitro-Ru complex may have been preventing hydrogen generation prior to nearly complete nitrite destruction in earlier tests. A new hypothesis can be made that a nitro-Ru complex is a necessary precursor to the catalytically active form of Ru for hydrogen generation. Consequently, by never forming the nitro-Ru complex in the nitrite-free SRAT run, the catalytically active form never had a chance to form. 


\subsection{CONCLUSIONS}

Two SRAT simulations were completed using a nitrite-free starting simulant, one with $\mathrm{Rh}$ and $\mathrm{Hg}$ and the other with $\mathrm{Ru}$ and $\mathrm{Hg}$. Noble metals were trimmed at the high end of the recent Rh-Ru-Hg study. Mercury was trimmed at $1.5 \mathrm{wt} \%$ in the total solids. Excess acid comparable in quantity to that in the recent $\mathrm{Rh}-\mathrm{Ru}-\mathrm{Hg}$ matrix study was used. In spite of the favorable conditions for hydrogen generation, virtually no hydrogen production was observed during either SRAT simulation.

The $\mathrm{Rh}$ test result confirms the postulated significance of nitrite ion to the catalytic reactions producing hydrogen in CPC testing with normal SRS simulants. As for Ru, however, previous testing has shown that $\mathrm{Ru}$ activated for hydrogen generation only after nitrite destruction. Therefore, Ru could have potentially been catalytically active for hydrogen production from the start of the nitrite-free SRAT test but no such activity was seen. The Ru test result suggests that the intermediate $\mathrm{Ru}$ form detected in the bead-frit melter feed preparation noble metal solubility profiles was some form of nitro-Ru complex. The nitro$\mathrm{Ru}$ complex is apparently not catalytically active for hydrogen generation but is a precursor to the catalytically active form (presumably a different complex not involving nitrite ligands). Removing nitrite ion from the system prevented the Ru catalyst precursor from forming and consequently prevented the catalytically active form.

The new data add to the overall fundamental understanding of catalytic hydrogen generation during SRS waste processing in the DWPF. When combined with results from an earlier SRAT simulation in which sodium nitrite was metered into the vessel to inhibit ligand substitution reactions and hydrogen generation, the new findings have greatly clarified the role of the nitrite ion in catalytic SRAT hydrogen generation reactions. These findings address one of the issues related to nitrite ion raised in the Future Work section of the recent summary document concerning catalytic hydrogen generation in the CPC. ${ }^{1}$ 


\subsection{ACKNOWLEDGMENTS}

I would like to acknowledge the assistance of M. F. Williams in preparing the GC's for operation during these tests. The GC data were critical to any evaluation of catalytic hydrogen generation. Method development was required to deal with the internal back flush on one of the GCs to reach a point where post-run reprocessing could extract reasonable values for the internal standard concentration (helium). I would also like to acknowledge the work of J. W. DuVall and D. P. Healy in preparing the nitrite-free simulant, and their assistance, along with V. J. Williams, I. A. Reamer, and T. O. Burckhalter in completing the SRAT simulations. I also wish to thank D. R. Best, P. Simmons, and W. T. Riley for the majority of the sample analyses. 


\subsection{REFERENCES}

${ }^{1}$ Koopman, D. C., DWPF Catalytic Hydrogen Generation Program - Review of Current Status, SRNL-STI-2009-00214, SRNL, Aiken, SC, 29808 (July 2009).

${ }^{2}$ Lambert, D. P., B. R. Pickenheim, and D. R. Best, DWPF SB6 Initial CPC Flowsheet Testing - SB6-1 to SB6-6 4L Tests of SB6-A and SB6-B Simulants, SRNL-STI-2009-00413, SRNL, Aiken, SC, 29808 (July 2009).

${ }^{3}$ Koopman, D. C., Statistical Evaluation of Processing Data from the Rh-Ru-Hg Matrix Study, SRNL-STI-2009-00084, SRNL, Aiken, SC, 29808 (April 2009).

${ }^{4}$ Koopman, D. C., Preliminary Evaluations of Two Proposed Stoichiometric Acid Equations, SRNL-L3100-2009-00146, SRNL, Aiken, SC, 29808 (June 2009).

5 Jantzen, C. M. and M. E. Stone, Role of Manganese Reduction/Oxidation (RedOx) on Foaming and Melt Rate in High Level Waste Melters, WSRC-STI-2006-00066, Savannah River National Laboratory, Aiken, SC, 29808 (March 2007). 


\section{Distribution:}

S. L. Marra, 773-A

A. B. Barnes, 999-W

D. A. Crowley, 773-43A

S. D. Fink, 773-A

B. J. Giddings, 786-5A

C. C. Herman, 999-W

F. M. Pennebaker, 773-42A

J. E. Occhipinti, 704-S

D. C. Sherburne, 704-S

R. T. McNew, 704-27S

J. F. Iaukea, 704-30S

J. W. Ray, 704-S

H. B. Shah, 766-H

J. M. Gillam, 766-H

B. A. Hamm, 766-H

D. D. Larsen, 766-H

C. J. Bannochie, 773-42A

D. K. Peeler, 999-W

N. E. Bibler, 773-A

M. E. Stone, 999-W

B. R. Pickenheim, 999-W

J. D. Newell, 999-W

A. I. Fernandez, 999-W

J. M. Pareizs, 773-A

S. H. Reboul, 773-A

J. M. Bricker, 704-27S

T. L. Fellinger, 704-26S

E. W. Holtzscheiter, 704-15S

M. T. Keefer, 766-H 